\title{
Base-Free and Acceptorless Dehydrogenation of Alcohols Catalyzed by an Iridium Complex Stabilized by a N,N,N-Osmaligand
}

\author{
Roberto G. Alabau, Miguel A. Esteruelas,* Antonio Martínez, Montserrat Oliván, and Enrique Oñate \\ Departamento de Química Inorgánica - Instituto de Síntesis Química y Catálisis Homogénea (ISQCH) - Centro de Innova- \\ ción en Química Avanzada (ORFEO-CINQA), Universidad de Zaragoza - CSIC, 50009 Zaragoza, Spain \\ Supporting Information Placeholder
}

\begin{abstract}
The preparation of a N,N,N-osmaligand, its coordination to iridium to afford an efficient catalyst precursor, and the catalytic activity of the latter in dehydrogenation reactions of hydrogen carriers based on alcohols are reported. Complex $\mathrm{OsH}_{2} \mathrm{Cl}_{2}\left(\mathrm{P}^{\mathrm{i}} \mathrm{Pr}_{3}\right)_{2}$ (1) reacts with 3-(2-pyridyl)pyrazol to give the osmium(II) complex $\mathbf{2} \mathbf{H}$, which contains an acidic hydrogen atom. Deprotonation of the latter by the bridging methoxy groups of the dimer $\left[\operatorname{Ir}(\mu-\mathrm{OMe})\left(\eta^{4}-\mathrm{COD}\right)\right]_{2}(\mathrm{COD}=1,5$-cyclooctadiene $)$ leads to $\operatorname{Ir}(\mathbf{2})\left(\eta^{4}-\mathrm{COD}\right)(\mathbf{3})$, where the osmaligand $\mathbf{2}$ has a free-nitrogen atom. Iridium complex $\mathbf{3}$ catalyzes the dehydrogenation of secondary and primary alcohols to ketones and aldehydes or esters, respectively, and the dehydrogenation of diols to lactones. Cyclooctatriene is detected during the catalysis by GC-MS, suggesting that the true catalyst of the reactions is a dihydride $\mathrm{IrH}_{2}(\mathbf{2})$ species with the osmaligand $\mathbf{2}$ acting as N,N,N-pincer. The presence of a phenyl group in the substrates favors the catalytic processes. The dehydrogenative homocoupling of primary alcohols to esters appears to take place via the transitory formation of hemiacetals.
\end{abstract}

\section{INTRODUCTION}

Metalloligands are coordination complexes, including organometallic species, bearing binding groups which can coordinate to other metal center. ${ }^{1}$ The presence of the metallic core in the metalloligand allows a wide variety of dispositions for its donor atoms. This enlarges the range of geometries that can be stabilized around of the new metal center. Furthermore, as a consequence of the presence of empty and full $d$ orbitals in the metal, the metalloligands generally possess variable electronic character, which is transmitted through the donor groups. ${ }^{2}$ This property has given rise to significant enhancements in catalytic activity of some metal centers in notable reactions. ${ }^{3}$ Ferrocene compounds containing donor substituents are most probably the best known ligands of this class. The ferrocene moiety provides specific geometries and opens the door to the control of reactivity at the additional metal center due to the possibility of switching the redox state of the iron center. ${ }^{4}$

Metalloligands are having a notable influence in modern organic synthesis by stabilizing a wide range of homogeneous catalysts for cross-coupling, hydrogenation, allylic substitution, hydroformylation, cyclopropanation, among other reactions of relevance. ${ }^{5}$ However, the metalloligand strategy has been scarcely applied to the acceptorless alcohol dehydrogenation, ${ }^{6}$ which is an oxidant-free atom-economical approach for the transformation of these molecules to carbonyl compounds and has great interest in connection with the hydrogen production from biomass and the storage-transport of hydrogen in organic liquids. ${ }^{7}$

Acceptorless alcohol dehydrogenation is generally an endothermic reaction at room temperature. Nevertheless, the equilibrium can be driven by removal the generated molecular hydrogen. High temperatures and strong basic media are often employed to promote the catalysis. ${ }^{8}$ The base is in principle able to deprotonate the alcohol. The resulting alkoxide then binds to the metal to generate a hydride by $\beta$-hydrogen elimination. Some ligands are described as noninnocent, giving rise to bifunctional complexes which can be engaged in deprotonation-protonation steps, and avoid the use of additional bases. ${ }^{9}$ The basic center of the ligands can reside in an atom bonded to the metal center (first coordination sphere) or in a remote position. Recent studies of Dub, Gordon, and coworkers; ${ }^{10}$ and Guse $^{11}$ call into question the noninnocent character of these ligands and therefore the bifunctional role of the catalysts. Their results reveal that the ligands are involved in the catalysis via the stabilization of some transition states through hydrogen bonding interactions and not via a reversible proton transfer.

$\pi$-Conjugated azolate ligands are particularly efficient in the transmission of information between distant metal centers. ${ }^{3,5 b, 12}$ Taking into account this background, we have designed a strongly basic tridentate $N$-donor metalloligand bearing an osmium(II) core, based on the 3-(2-pyridyl)pyrazolate moiety, in the search of a novel class of catalysts for the acceptorless and base-free alcohol dehydrogenation. In this paper, we report the preparation of a novel osmaligand and its coordination to iridium, which generates an efficient catalyst for the acceptorless and base-free dehydrogenation of secondary and primary alcohols as well as diols.

\section{RESULST AND DISCUSSION}

Preparation of the Osmaligand and its Coordination to Iridium: Synthesis of the Catalytic Precursor. Complex $\mathrm{OsH}_{2} \mathrm{Cl}_{2}\left(\mathrm{P}^{\mathrm{i}} \mathrm{Pr}_{2}\right)_{2}$ (1) has been one of the cornerstones in the development of the modern osmium chemistry due to its abil- 
ity to act as starting compound in the preparation of a wide variety of complexes. ${ }^{13}$ In the light of these precedents, we decided to use it in order to prepare our osmaligand. Treatment of toluene solutions of 1 with 3.3 equiv of 3-(2pyridyl)pyrazol (3-py-pzH), in the presence of (piperidinomethyl)polystyrene, for $5.5 \mathrm{~h}$, under reflux lead to $\mathbf{2 H}$ (eq 1), which was isolated as a dark green solid in $52 \%$ yield. The most noticeable spectroscopic features of this species, in benzene- $d_{6}$, at room temperature are a broad signal at $17.60 \mathrm{ppm}$, in the ${ }^{1} \mathrm{H}$ NMR spectrum, corresponding to the NH-nitrogen atom and a singlet at $-2.2 \mathrm{ppm}$, in the ${ }^{31} \mathrm{P}\left\{{ }^{1} \mathrm{H}\right\}$ NMR spectrum, due to the coordinated phosphine. In contrast to $\mathbf{1}$, the $d^{2}$ hexahydride complex $\mathrm{OsH}_{6}\left(\mathrm{P}^{\mathrm{i}} \mathrm{Pr}_{3}\right)_{2}$ reacts with 3-py-pzH to give the osmium(IV)-trihydride derivative $\mathrm{OsH}_{3}\left\{\kappa^{2}-N, N-(3-\right.$ py-pz) $\}\left(\mathrm{P}^{\mathrm{i}} \mathrm{Pr}_{3}\right)_{2}{ }^{14}$

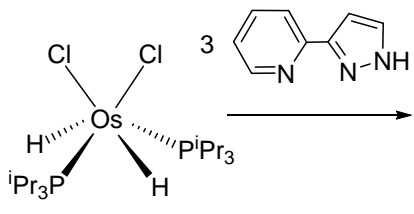

1

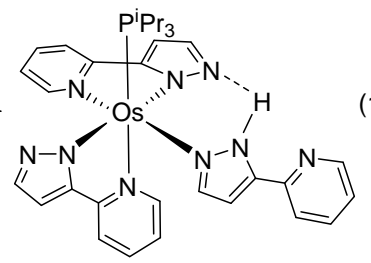

$2 \mathrm{H}$

Complex $\mathbf{2 H}$ can be deprotonated by the bridging methoxy groups of the dimer $\left[\operatorname{Ir}(\mu-\mathrm{OMe})\left(\eta^{4}-\mathrm{COD}\right)\right]_{2}(\mathrm{COD}=1,5-$ cyclooctadiene). The deprotonation produces the coordination of two free nitrogen atoms of the metalloligand to iridium. Thus, the addition of 0.5 equiv of this dimer to acetone solutions of $\mathbf{2 H}$ affords the heterobimetallic derivative $\mathbf{3}$ (eq 2), which was isolated as a dark brown solid in $78 \%$ yield.

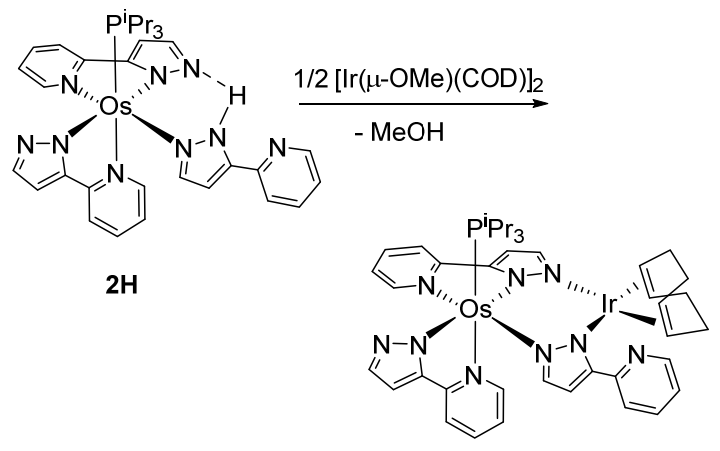

3

Complex 3 was characterized by X-ray diffraction analysis. Figure 1 shows a view of the molecule. The structure proves the formation of the osmaligand and its coordination to the $\operatorname{Ir}\left(\eta^{4}-\mathrm{COD}\right)$ moiety. The metalloligand can be rationalized as an octahedral osmium(II) complex containing a triisopropylphosphine ligand and three different 3-(2pyridyl)pyrazolate groups; chelate, chelate-bridge, and bridge. The phosphine ligand is disposed trans to the pyridyl group of the chelate ligand $\left(\mathrm{P}(1)-\mathrm{Os}-\mathrm{N}(9)=174.3(2)^{\circ}\right)$, whereas the $\mathrm{pz}-$ ring is located trans to the pz-ring of the chelate-bridge ligand $\left(\mathrm{N}(7)-O s-\mathrm{N}(4)=166.5(3)^{\circ}\right)$. The pyridyl group of the latter lies trans to the bridging ligand $\left(\mathrm{N}(6)-\mathrm{Os}-\mathrm{N}(2)=164.1(3)^{\circ}\right)$. This geometry disposes three nitrogen atoms with free electron pairs, the pyrazolic $\mathrm{N}(1)$ and $\mathrm{N}(5)$ and pyridinic $\mathrm{N}(3)$, which can act as a pincer. Nevertheless, the metalloligand only coordinates the pyrazolic $\mathrm{N}(1)$ and $\mathrm{N}(5)$ atoms to the $\operatorname{Ir}\left(\eta^{4}-\mathrm{COD}\right)$ moiety $\left(\mathrm{N}(1)-\operatorname{Ir}-\mathrm{N}(5)=89.5(3)^{\circ}\right)$ to form a square-planar iridium(I) species, in agreement with the high stability of the $d^{8}$ - compounds of this geometry. If $\mathrm{M}(1)$ is the midpoint of the coordinated $\mathrm{C}(25)-\mathrm{C}(26)$ double bond and $\mathrm{M}(2)$ is the midpoint of the related $\mathrm{C}(29)-\mathrm{C}(30)$ bond, the $\mathrm{N}(1)-\mathrm{Ir}-\mathrm{M}(2)$ and $\mathrm{N}(5)-\operatorname{Ir}-\mathrm{M}(1)$ angles are $175.0^{\circ}$ and $173.3^{\circ}$, respectively. The 1,5-cyclooctadiene ligand takes its customary "tub" conformation. The coordinated bonds have lengths of 1.426(15) $(\mathrm{C}(25)-\mathrm{C}(26))$ and $1.392(15)(\mathrm{C}(29)-\mathrm{C}(30)) \AA$, which are longer than the $\mathrm{C}-\mathrm{C}$ double bonds in the free diene $(1.34 \AA),{ }^{15}$ in accordance with the usual Chatt-Dewar-Duncanson model. In agreement with the lack of symmetry of the molecule, the ${ }^{1} \mathrm{H}$ NMR spectrum in benzene- $d_{6}$ at room temperature and in toluene- $d_{8}$ at $-50^{\circ} \mathrm{C}$ displays four olefinic $\mathrm{C}\left(\mathrm{sp}^{2}\right)-\mathrm{H}$ resonances. Two of them appear together at about $3.4 \mathrm{ppm}$, while the other two resonances are observed at about 4.7 and $2.8 \mathrm{ppm}$. Consistently, the ${ }^{13} \mathrm{C}\left\{{ }^{1} \mathrm{H}\right\}$ NMR spectrum in fluorobenzene at $30^{\circ} \mathrm{C}$ shows four singlets at $69.0,66.8,66.2$, and $57.6 \mathrm{ppm}$ for the $\mathrm{C}\left(\mathrm{sp}^{2}\right)$ carbon atoms of the diene. The separation between the iridium atom and the core of the metalloligand is long, 3.9317(6) A.

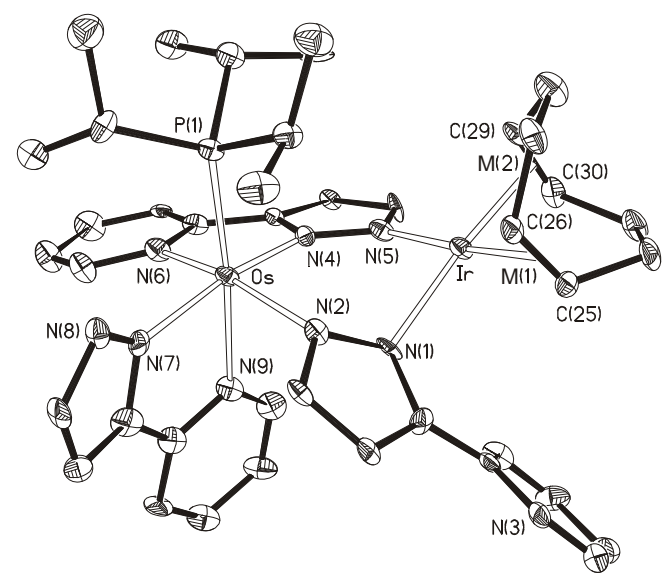

Figure 1. Molecular diagram of complex $3(50 \%$ probability ellipsoids). All hydrogen atoms are omitted for clarity. Selected bond lengths $(\AA)$ and angles $(\mathrm{deg})$ : Os- $\mathrm{P}(1)=2.326(3)$, Os- $\mathrm{N}(2)=$ 2.132(8), Os- $\mathrm{N}(4)=2.048(9)$, Os-N(6) $=2.083(8)$, Os-N(7) $=$ 2.075(9), Os-N(9) = 2.157(8), Ir-N(1) = 2.131(8), Ir-N(5) = $2.079(9), \mathrm{C}(25)-\mathrm{C}(26)=1.426(15), \mathrm{C}(29)-\mathrm{C}(30)=1.392(15)$; $\mathrm{P}(1)-\mathrm{Os}-\mathrm{N}(9)=174.3(2), \mathrm{N}(4)-\mathrm{Os}-\mathrm{N}(6)=77.9(3), \mathrm{N}(7)-\mathrm{Os}-\mathrm{N}(9)$ $=77.4(3), \mathrm{N}(1)-\operatorname{Ir}-\mathrm{N}(5)=89.5(3), \mathrm{N}(1)-\operatorname{Ir}-\mathrm{M}(2)=175.0, \mathrm{~N}(5)-\mathrm{Ir}-$ $\mathrm{M}(1)=173.3, \mathrm{M}(1)-\mathrm{Ir}-\mathrm{M}(2)=86.4$.

Dehydrogenation of Secondary and Primary Alcohols and Diols. Complex 3 is a catalyst precursor for the base-free and acceptorless dehydrogenation of the above mentioned hydrogen donors. As expected the rate of the reaction increases as the precursor concentration increases (see Figure S1), reaching an optimal equilibrium between conversion and time required when the catalyst loading was $5 \%$ mol. Thus, the reactions were performed in toluene at $100{ }^{\circ} \mathrm{C}$, using a substrate concentration of $0.19 \mathrm{M}$ and a $5 \% \mathrm{~mol}$ of iridium complex.

Table 1 collects the studied secondary alcohols and the yields of their dehydrogenation reactions to the corresponding ketones (eq 3), after $18 \mathrm{~h}$. 1-Phenylethanol (run 1) and related alcohols with a substituent at the phenyl groups (runs 2-6) are efficiently dehydrogenated into the ketones with yields between $63 \%$ and $95 \%$. Under the same conditions, the iridium complex $\operatorname{Ir}\left\{\kappa^{2}-N, N-[3-p y-p z]\right\}\left(\eta^{4}-\mathrm{COD}\right)^{16}$ affords $15 \%$ of acetophenone, demonstrating that the metalloligand $\mathbf{2}$ is more 
efficient than the 3-(2-pyridyl)pyrazolate ligand from a catalytic point of view. Chloride and methyl substituents at the para position have little influence in the amount of formed ketone (runs 2 and 3), while methoxy clearly favors the dehydrogenation. Jones and co-workers have conversely observed that, in the presence of nickel(II) precursors supported by tris(3,5-dimethylpyrazolyl)borate and 2-hydroxyquinolines, para-substituted 1-phenylethanol alcohols bearing electrondonating groups react much more slowly than those with electron-withdrawing substituents. ${ }^{17}$ In the presence of $\mathbf{3}$, the substituent of the phenyl group influences the dehydrogenation when is close to the alcohol function, decreasing the amount of formed ketone. The same trend has been observed for the dehydrogenations of methyl-substituted 1-phenylethanol alcohols catalyzed by the osmium precursor $\mathrm{OsH}_{3}\left\{\kappa^{2}-N_{\text {py }}, N_{\text {imine }}{ }^{-}\right.$ $(\mathrm{BMPI})\}\left(\mathrm{P}^{\mathrm{i}} \mathrm{Pr}_{3}\right)_{2} \quad\left(\mathrm{BMPI}=1,3\right.$-bis $\left(6^{\prime}\right.$-'methyl-2'pyridylimino)isoindolinate). ${ }^{18}$ The increase of the steric hindrance in the vicinity of the $\mathrm{OH}$ group certainly hinders the dehydrogenation. Thus, diphenylmethanol (run 7) is dehydrogenated with the same efficiency $(61 \%)$ as 1 -(o-tolyl)ethanol (63\%; run 6); i.e., worse than 1-phenylethanol (78\%). For the trihydride-Os-BMPI precursor, however, the adverse impact resulting from the increase of the steric hindrance in the proximity of the functional group is compensated for the higher stability of benzophenone with regard to acetophenone. Thus, in contrast to $\mathbf{3}$, it oxidizes 1-diphenylmethanol better than 1phenylethanol $(77 \%$ versus $60 \%) .{ }^{18}$ Alcohols with two alkyl groups, such as 2-octanol and 1-cyclohexylethanol (runs 8 and 9) are dehydrogenated worse than diphenylmethanol. 2Octanone and cyclohexyl methyl ketone are obtained in $40 \%$ and 50\% yield, respectively. Complex 3 also dehydrogenates functionalized alcohols. 1-(4-Pyridyl)ethanol (run 10), 1-(3pyridyl)ethanol (run 11), and 1-(2-furyl)ethanol (run 12) are transformed into the corresponding ketones and molecular hydrogen in $31 \%, 45 \%$, and $56 \%$ yield, respectively. The increase in the amount of produced hydrogen as the heteroatom of the heterocycle approaches to the alcohol function agrees well with that observed for the iron precursor $\mathrm{Fe}\left(\eta^{5}\right.$ $\left.\mathrm{C}_{5} \mathrm{H}_{5}\right) \mathrm{Cl}(\mathrm{CO})_{2}$ in the presence of $\mathrm{NaH}$; while 2pyridylmethanol derivatives are efficiently dehydrogenated, 4pyridylmethanol and 3-pyridylmethanol do not undergo oxidation under the same conditions. ${ }^{8 \mathrm{e}}$

Table 1. Acceptorless and Base-Free Dehydrogenation of Secondary Alcohols Catalyzed by $3^{\text {a }}$

Sun Yield (\%)

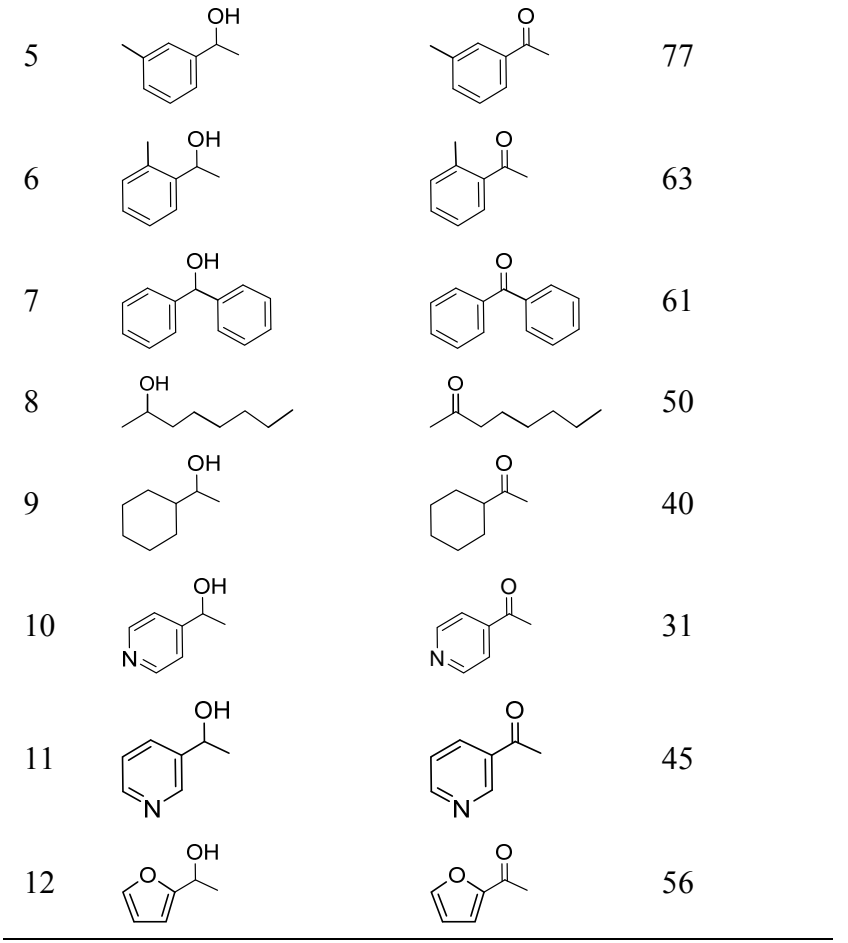

${ }^{\mathrm{a}}$ Conditions: Complex $3(0.0093 \mathrm{mmol})$; substrate $(0.19 \mathrm{mmol})$; toluene $(1 \mathrm{~mL})$ heated at $100{ }^{\circ} \mathrm{C}$ for $18 \mathrm{~h} .{ }^{\mathrm{b}}$ Conversions were calculated from the relative peak area integrations of the reactant and product in the GC spectra.

$$
\overbrace{\mathrm{R}^{\prime}}^{\mathrm{OH}} \frac{\begin{array}{c}
\text { toluene } \\
100^{\circ} \mathrm{C}, 18 \mathrm{~h}
\end{array}}{\mathrm{R}^{\prime}} \stackrel{\mathrm{I}_{\mathrm{R}^{\prime}}}{\mathrm{O}}+\mathrm{H}_{2}
$$

Dehydrogenation of primary alcohols is more challenging than the dehydrogenation of secondary alcohols, since the aldehydes resulting from the former can generate inactive carbonyl complexes. ${ }^{19}$ Alternatively to aldehydes, these alcohols form esters as a consequence of a dehydrogenative homocoupling. ${ }^{20}$ Complex 3 promotes both processes: the dehydrogenation to aldehydes (eq 4) and the dehydrogenative homocoupling to yield esters (eq 5). The reactions were performed under the same conditions as those used for promoting the dehydrogenation of secondary alcohols. Table 2 collects the studied alcohols, the percentage of alcohol dehydrogenated after $18 \mathrm{~h}$, the formed oxidized products, and the percentages of alcohol transformed into each one of them; i.e., the percentage of molecular hydrogen generated according to eqs 4 and 5. Benzyl alcohol (run 1) and related alcohols with a substituent at the phenyl group (runs 2-7) are efficiently dehydrogenated in $86 \%-97 \%$. The products resulting from the oxidation show a marked dependence upon the substituents. Electron donating groups at para position favor the dehydrogenation according to eq 4 and therefore the formation of aldehydes. However, electron withdrawing substituents benefit the generation of esters; i.e., the dehydrogenation through eq 5 . There is a decreasing linear relationship between the percentage of alcohol 
Table 2. Acceptorless and Base-Free Dehydrogenation of Primary Alcohols Catalyzed by 3 a

\begin{tabular}{|c|c|c|c|c|c|c|}
\hline \multirow{2}{*}{ Run } & \multirow{2}{*}{ Substrate } & \multirow{2}{*}{$\begin{array}{l}\text { Dehydrogenated } \\
\text { alcohol }(\%)^{b}\end{array}$} & \multicolumn{4}{|c|}{ Alcohol transformed into } \\
\hline & & & Aldehyde (\%) & & Ester $(\%)^{b}$ & \\
\hline 1 & & 91 & & 76 & & 15 \\
\hline 2 & & 95 & & 17 & & 78 \\
\hline 3 & & 97 & & 62 & & 35 \\
\hline 4 & & 91 & & 88 & & 3 \\
\hline 5 & $\mathrm{OH}$ & 87 & & 82 & & 5 \\
\hline 6 & & 86 & & 70 & & 16 \\
\hline 7 & & 56 & & 48 & & 8 \\
\hline 8 & $\mathrm{H}$ & 26 & & 6 & & 20 \\
\hline 9 & & 45 & & 11 & & 34 \\
\hline 10 & & 42 & & 34 & & 8 \\
\hline 11 & $\mathrm{H}$ & 36 & -1 & 28 & & 6 \\
\hline
\end{tabular}

${ }^{\mathrm{a}}$ Conditions: Complex $3(0.0093 \mathrm{mmol})$; substrate $(0.19 \mathrm{mmol})$; toluene $(1 \mathrm{~mL})$ heated at $100{ }^{\circ} \mathrm{C}$ for $18 \mathrm{~h} .{ }^{\mathrm{b}} \mathrm{Calculated}$ by ${ }^{1} \mathrm{H} \mathrm{NMR}$ spectroscopy.

transformed into aldehyde according to eq 4 and the Hammett $\sigma_{\mathrm{p}}$ values of the substituent, ${ }^{21}$ which is consistent with the increasing linear relationship between the percentage of alcohol transformed into ester according to eq 5 and the above mentioned values (Figure 2).

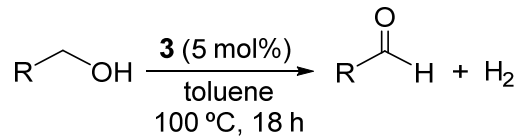

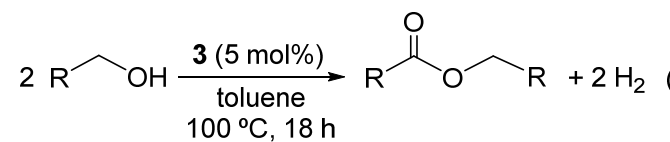

The position of the substituent mainly influences the amount of generated molecular hydrogen (runs 5-7), decreasing as the substituent approaches to the alcohol function, i.e, $p \approx m>o$ (runs $5 \approx 6>7$ ). Cyclohexylmethanol (run 8) and 1-octanol (run 9) are also dehydrogenated, although in lower extension ( $26 \%$ and $45 \%$, respectively). In these cases, the correspond- 
ing ester is the main oxidation product. In contrast, 2furanylmethanol (run 10) and 3-pyridylmethanol (run 11) are dehydrogenated in $42 \%$ and $36 \%$, respectively, mainly generating the aldehyde.

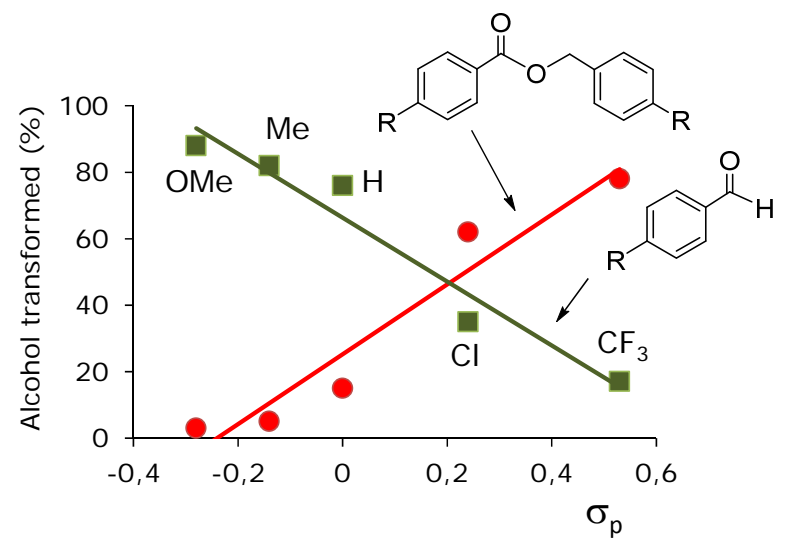

Figure 2. Percentages of alcohol transformed into aldehyde (green $\boldsymbol{\square}$ ) and ester (red $\bullet$ ) as a function of the Hammett $\sigma_{\mathrm{p}}$ values for the dehydrogenation of $p$-substituted benzyl alcohols.

Complex 3 also dehydrogenates diols to lactones. The presence of a phenyl group in the substrate favors the process as has been shown for secondary and primary alcohols in Tables 1 and 2. Thus, 1,2-phenylenedimethanol gives 1isobenzofuranone and molecular hydrogen in quantitative yield, after $18 \mathrm{~h}$ (eq 6), while 1,5-pentanediol affords tetrahydro- $2 \mathrm{H}$-pyran-2-one in $35 \%$ yield under the same conditions and the same time (eq 7). This class of reaction is of particular interest, since functionalized lactones are ubiquitous frameworks in a variety of biologically active natural products. Several catalysts have been developed for the reaction in the presence of hydrogen acceptors. ${ }^{20 a, 22}$ Catalysts working in the presence of bases are also known, ${ }^{22}$ while efficient systems under base-free and acceptorless conditions are more rare. ${ }^{20 b, 24}$

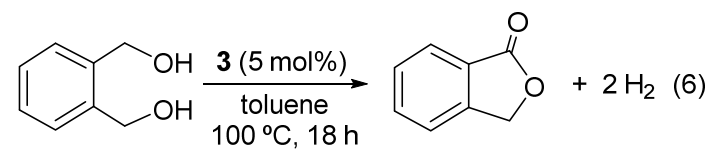

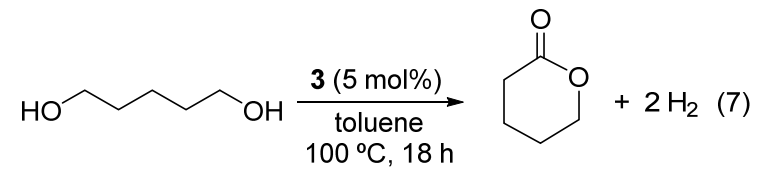

Cyclooctatriene is detected during the catalysis by GC-MS. This suggests the formation of a dihydride-iridium(III) species stabilized by a pincer-N,N,N-osmaligand. Pincer complexes active in acceptorless dehydrogenation of alcohols are known. ${ }^{25}$ This $(\mathrm{N}, \mathrm{N}, \mathrm{N}) \mathrm{IrH}_{2}$ species (A) should be the result of the dehydrogenation of the coordinated diene of $\mathbf{3}$ and of the coordination of the free nitrogen atom to the iridium center (Scheme 1) and can be viewed as a N,N,N-counterpart of the known dihydride (PCP) $\mathrm{IrH}_{2}$ complexes, which promote the acceptorless dehydrogenation of alkanes. ${ }^{26}$ Complex A would promote the dehydrogenation of the alcohols through the cycle shown in Scheme 1. The addition of the O-H bond of the alcohols to one of the Ir- $\mathrm{H}$ bonds of A should give the hydride-dihydrogen intermediate $\mathbf{B}$ containing an alkoxy ligand.
The addition could involve only one alcohol molecule or a dimer formed via $\mathrm{O}-\mathrm{H} \cdots \mathrm{O}$ hydrogen bond. Previous relevant DFT mechanistic studies have revealed that proton shuttle type transition states, involving a molecule of alcohol as a proton bridge, significantly decrease the activation energy of the $\mathrm{O}-\mathrm{H}$ rupture. ${ }^{27}$ Once complex $\mathbf{B}$ is formed, the dissociation of the coordinated hydrogen molecule should lead to the hydride-alkoxide $\mathbf{C}$. Then, this intermediate could undergo a $\beta$ hydrogen elimination reaction of the alkoxide group to afford the corresponding ketone or aldehyde and to regenerate $\mathbf{A}$.

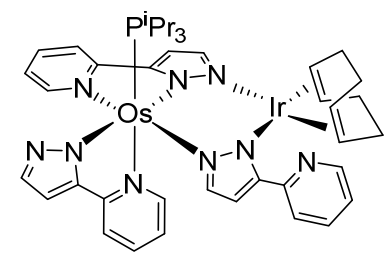

3<smiles>C1=CC=CCCC=C1</smiles>

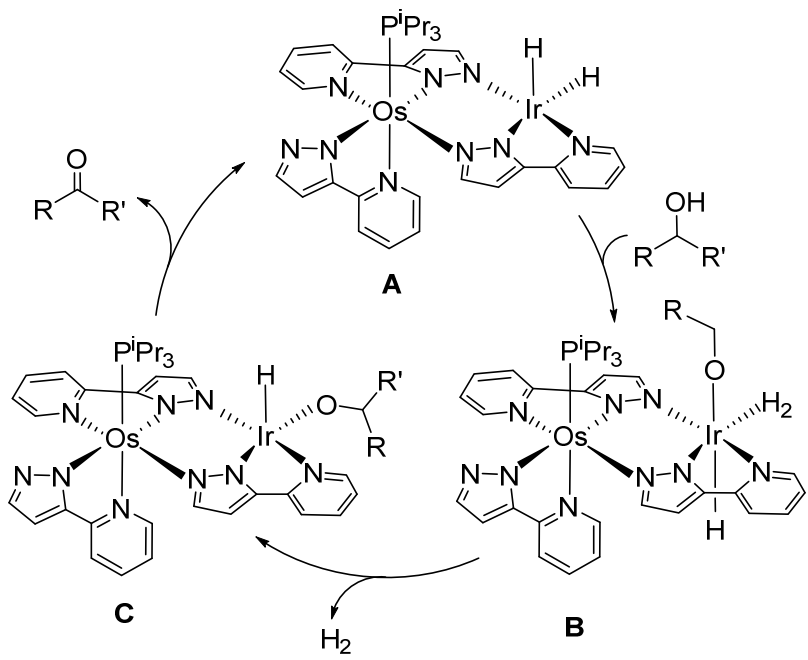

Scheme 1. Proposed catalytic cycle for the dehydrogenation of secondary alcohols. 


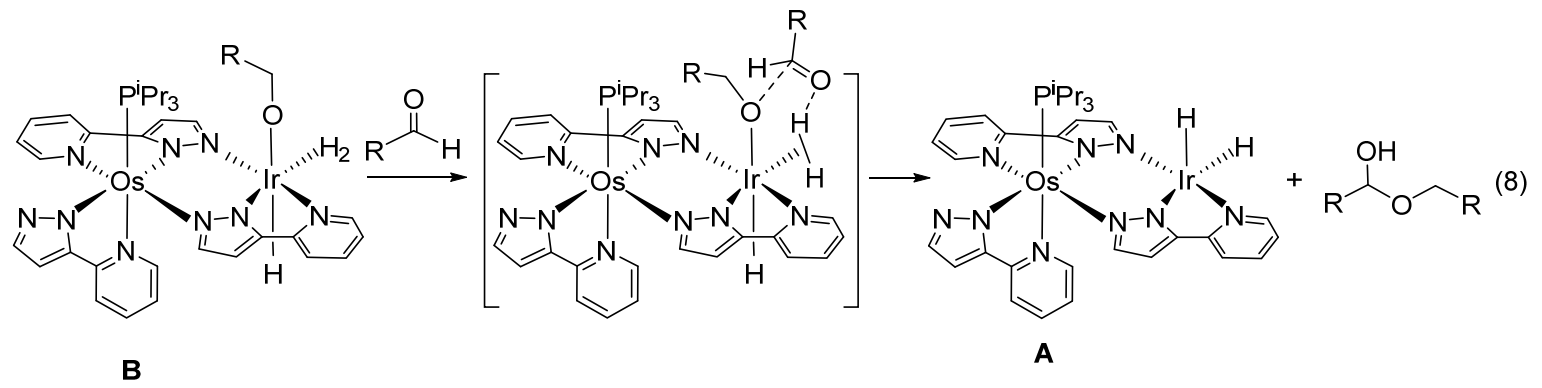

Esters, as alternative products to aldehydes in the dehydrogenation of primary alcohols, seem to be a result of the transitory formation of hemiacetals. These compounds can be generated by means of the reaction of intermediate $\mathbf{B}$ with a molecule of aldehyde previously formed, according to eq 8 . The carbon atom of the carbonyl group of the aldehyde removes the coordinated alkoxide group, whereas the oxygen atom abstracts the proton of the dihydrogen ligand. In agreement with this, it should be mentioned that, in a consistent manner with Figure 2, the natural bond orbital charge (b3lyp(GD3)6$311 \mathrm{G}^{* *}$ ) on the carbon atom of the carbonyl group of the aldehyde increases as the Hammett $\sigma_{p}$ value also increases (See Table S1) and that the protic character of the coordinated hydrogen molecule is a well known property of these ligands. ${ }^{28}$ Once the hemiacetal and $\mathbf{A}$ are formed, the latter can dehydrogenate to the ester as to any other alcohol.

\section{CONCLUDING REMARKS}

This study has revealed that the reaction of the known complex $\mathrm{OsH}_{2} \mathrm{Cl}_{2}\left(\mathrm{P}^{\mathrm{i}} \mathrm{Pr}_{3}\right)_{2}$ with 3-(2-pyridyl)pyrazol gives rise to an osmium(II) compound, which can act as a N,N-bidentate or $\mathrm{N}, \mathrm{N}, \mathrm{N}-$ pincer osmaligand by deprotonation. Thus, its coordination to iridium has allowed us to stabilize an efficient catalyst precursor for base-free and acceptorless dehydrogenation of secondary and primary alcohols and diols, which leads to ketones, aldehydes or esters, and lactones, respectively. The presence of a phenyl group in the substrates favors the reactions. The products of the dehydrogenation of benzyl alcohols bearing a substituent at the phenyl group shows a marked dependence upon the Hammett $\sigma_{\mathrm{p}}$ value of the substituent, which is consistent with the transitory formation of hemiacetals in the dehydrogenative homocoupling to generate esters.

In conclusion, a novel osmaligand, which allows to stabilize catalysts for base-free and acceptorless dehydrogenation of alcohols and diols has been discovered.

\section{EXPERIMENTAL SECTION}

General Information. The reactions were carried out under moisture- and oxygen-free atmosphere using dried solvents and Schlenktube techniques. Instrumental methods, X-ray information, and DFT computational details are given in the Supporting Information. In the NMR spectra, chemical shifts (expressed in parts per million) are referenced to residual solvent peaks $\left({ }^{1} \mathrm{H},{ }^{13} \mathrm{C}\left\{{ }^{1} \mathrm{H}\right\}\right)$ or external $\mathrm{H}_{3} \mathrm{PO}_{4}$ $\left({ }^{31} \mathrm{P}\right)$ and coupling constants $(J)$ are given in hertz. $\mathrm{OsH}_{2} \mathrm{Cl}_{2}\left(\mathrm{P}^{\mathrm{i}} \mathrm{Pr}_{3}\right)_{2}{ }^{29}$ and $\left[\operatorname{Ir}(\mu-\mathrm{OMe})\left(\eta^{4}-\mathrm{COD}\right)\right]_{2}^{30}$ were prepared by previously published methods.

Reaction of $\mathrm{OsCl}_{2} \mathrm{H}_{2}\left(\mathrm{P}^{\mathrm{i}} \mathrm{Pr}_{3}\right)_{2}$ (1) with 3-(2-pyridyl)pyrazol: Preparation of $\mathbf{2 H}$. A solution of $\mathbf{1}(200 \mathrm{mg}, 0.343 \mathrm{mmol})$ in toluene $(10 \mathrm{~mL})$ was treated with 3-(2-pyridyl)pyrazol (164.2 mg, 1.131 $\mathrm{mmol}$ ) and (piperidinomethyl)polystyrene (323 $\mathrm{mg}, 1.131 \mathrm{mmol})$. The resulting mixture was refluxed for $5.5 \mathrm{~h}$, getting a dark green solution. After cooling at room temperature the solution was filtered evaporated to dryness, affording a dark green residue. Further purification was carried out by silica gel (230-400 mesh, eluted previously with a $20 \%$ solution of $\mathrm{NEt}_{3}$ in pentane) column chromatography using a $1: 1$ mixture of pentane and $\mathrm{CH}_{2} \mathrm{Cl}_{2}$, followed by precipitation in pentane, giving a dark green solid. Yield: $140 \mathrm{mg}$ (52\%). Anal. calcd. for $\mathrm{C}_{33} \mathrm{H}_{40} \mathrm{~N}_{9} \mathrm{OsP}$ : C, 50.56; H, 5.14; N, 16.08; found: C, 50.30; H, 4.86; $\mathrm{N}, 16.37$. HRMS (electrospray, m/z) calcd for $\mathrm{C}_{33} \mathrm{H}_{39} \mathrm{~N}_{9} \mathrm{NaOsP}[\mathrm{M}-$ $\mathrm{H}+\mathrm{Na}]^{+}$: 807.2574; found: 807.2576. ${ }^{1} \mathrm{H}$ NMR $\left(300 \mathrm{MHz}, \mathrm{C}_{6} \mathrm{D}_{6}, 298\right.$ $\mathrm{K}): \delta 17.60(\mathrm{br}, 1 \mathrm{H}, \mathrm{N}-\mathrm{H}), 8.47\left(\mathrm{~d}, J_{\mathrm{H}-\mathrm{H}}=4.1,1 \mathrm{H}, \mathrm{py}\right), 8.41\left(\mathrm{~d}, J_{\mathrm{H}-\mathrm{H}}=\right.$ $2.1,1 \mathrm{H}, \mathrm{pz}), 8.35\left(\mathrm{~d}, J_{\mathrm{H}-\mathrm{H}}=2.1,1 \mathrm{H}, \mathrm{pz}\right), 7.97\left(\mathrm{~d}, J_{\mathrm{H}-\mathrm{H}}=5.7,1 \mathrm{H}, \mathrm{py}\right)$, $7.13\left(\mathrm{~d}, J_{\mathrm{H}-\mathrm{H}}=1.8,1 \mathrm{H}, \mathrm{pz}\right), 7.00-6.89(\mathrm{~m}, 5 \mathrm{H}, 1 \mathrm{H} \mathrm{pz}$ and $4 \mathrm{H}$ py), 6.83 $\left(\mathrm{d}, J_{\mathrm{H}-\mathrm{H}}=1.8,1 \mathrm{H}, \mathrm{pz}\right), 6.72\left(\mathrm{~d}, J_{\mathrm{H}-\mathrm{H}}=5.6,1 \mathrm{H}, \mathrm{py}\right), 6.44\left(\mathrm{dd}, J_{\mathrm{H}-\mathrm{H}}=\right.$ $\left.7.7, J_{\mathrm{H}-\mathrm{H}}=0.8,1 \mathrm{H}, \mathrm{py}\right), 6.37\left(\mathrm{t}, J_{\mathrm{H}-\mathrm{H}}=7.7,1 \mathrm{H}, \mathrm{py}\right), 6.29\left(\mathrm{t}, J_{\mathrm{H}-\mathrm{H}}=7.7\right.$, $1 \mathrm{H}$, py), $6.17\left(\mathrm{~d}, J_{\mathrm{H}-\mathrm{H}}=2.1,1 \mathrm{H}, \mathrm{pz}\right), 5.80(\mathrm{~m}, 1 \mathrm{H}, \mathrm{py}), 5.61\left(1 \mathrm{H}, J_{\mathrm{H}-\mathrm{H}}\right.$ $=6.5,1 \mathrm{H}$, py), $2.83\left(\mathrm{~m}, 3 \mathrm{H}, \mathrm{PCH}\left(\mathrm{CH}_{3}\right)_{2}\right), 1.11\left(\mathrm{dd}, J_{\mathrm{H}-\mathrm{H}}=6.9, J_{\mathrm{H}-\mathrm{P}}=\right.$ $\left.7.5,9 \mathrm{H}, \mathrm{PCH}\left(\mathrm{CH}_{3}\right)_{2}\right), 1.07\left(\mathrm{dd}, J_{\mathrm{H}-\mathrm{H}}=7.2, J_{\mathrm{H}-\mathrm{P}}=7.5,9 \mathrm{H}\right.$, $\left.\mathrm{PCH}\left(\mathrm{CH}_{3}\right)_{2}\right) .{ }^{13} \mathrm{C}\left\{{ }^{1} \mathrm{H}\right\}$ NMR $\left(75.47 \mathrm{MHz}, \mathrm{C}_{6} \mathrm{D}_{6}, 298 \mathrm{~K}\right): \delta 161.8(\mathrm{~s}$, C), 158.2 (s, C), 154.4 (s, CH py), 151.6 (s, C), 150.6 (s, C), 150.3 (s, CH py), 148.3 (s, C), 147.4, 144.5, 144.0 (s, C), 140.3, 137.8, 136.3, $135.0,132.3,122.2,120.2,119.9,119.5,117.3,109.9,104.3$ (all s, $\mathrm{CH}$ py and pz), $26.5\left(\mathrm{~d}, J_{\mathrm{C}-\mathrm{P}}=24.1, \mathrm{PCH}\left(\mathrm{CH}_{3}\right)_{2}\right), 20.0$ (s, $\left.\mathrm{PCH}\left(\mathrm{CH}_{3}\right)_{2}\right) .{ }^{31} \mathrm{P}\left\{{ }^{1} \mathrm{H}\right\} \mathrm{NMR}\left(121.49 \mathrm{MHz}, \mathrm{C}_{6} \mathrm{D}_{6}, 298 \mathrm{~K}\right): \delta-2.2$.

Reaction of $2 \mathrm{H}$ with $\left[\operatorname{Ir}(\mu-\mathrm{OMe})\left(\eta^{4}-\mathrm{COD}\right)\right]_{2}$ : Preparation of 3. A solution of $\mathbf{2 H}(140 \mathrm{mg}, 0.18 \mathrm{mmol})$ in acetone $(5 \mathrm{~mL})$ was treated with $\left[\operatorname{Ir}(\mu-\mathrm{OMe})\left(\eta^{4}-\mathrm{COD}\right)\right]_{2}(59 \mathrm{mg}, 0.09 \mathrm{mmol})$ and the resulting mixture was stirred at room temperature for 18 hours. After this time, the dark brown solution was evaporated to dryness to afford a darkbrown residue. Methanol was added to afford a dark-brown solid, which was washed with methanol $(2 \times 1 \mathrm{~mL})$ and dried in vacuo. Yield: $150 \mathrm{mg}(78 \%)$. Anal. calcd. for $\mathrm{C}_{41} \mathrm{H}_{51} \mathrm{IrN}_{9} \mathrm{OsP}$ : C, 45.46; $\mathrm{H}$, 4.74; N, 11.63; found: C, 45.24; H, 4.43; N, 11.92. HRMS (electrospray, $\mathrm{m} / \mathrm{z}$ ) calcd for $\mathrm{C}_{41} \mathrm{H}_{51} \mathrm{IrN}_{9} \mathrm{OsP}[\mathrm{M}]^{+}$: 1085.3248; found: 1085.3276. IR $\left(\mathrm{cm}^{-1}\right): v(\mathrm{C}=\mathrm{N}), v(\mathrm{C}=\mathrm{C}) 1603(\mathrm{~m}), 1586(\mathrm{~m}) .{ }^{1} \mathrm{H}$ NMR $\left(300 \mathrm{MHz}, \mathrm{C}_{6} \mathrm{D}_{6}, 298 \mathrm{~K}\right): \delta 8.73\left(\mathrm{~d}, J_{\mathrm{H}-\mathrm{H}}=7.8,1 \mathrm{H}, \mathrm{py}\right), 8.52(\mathrm{~m}, 1 \mathrm{H}$, pz), $8.32\left(\mathrm{~d}, J_{\mathrm{H}-\mathrm{H}}=1.9,1 \mathrm{H}, \mathrm{pz}\right), 7.90\left(\mathrm{~d}, J_{\mathrm{H}-\mathrm{H}}=6,1 \mathrm{H}, \mathrm{py}\right), 7.75\left(\mathrm{~d}, J_{\mathrm{H}-}\right.$ $\mathrm{H}=2.7,1 \mathrm{H}, \mathrm{pz}), 7.34\left(\mathrm{td}, J_{\mathrm{H}-\mathrm{H}}=6.0, J_{\mathrm{H}-\mathrm{H}}=1.9,1 \mathrm{H}, \mathrm{py}\right), 7.05\left(\mathrm{~d}, J_{\mathrm{H}-\mathrm{H}}\right.$ $=2.1,1 \mathrm{H}, \mathrm{pz}), 6.85-6.63(\mathrm{~m}, 5 \mathrm{H}, 2 \mathrm{H} \mathrm{pz}$ and $3 \mathrm{H} \mathrm{py}), 6.56\left(\mathrm{~d}, J_{\mathrm{H}-\mathrm{H}}=\right.$ $1.8,1 \mathrm{H}, \mathrm{py}), 6.49$ (d, $\left.J_{\mathrm{H}-\mathrm{H}}=6,1 \mathrm{H}, \mathrm{py}\right), 6.40-6.26(\mathrm{~m}, 2 \mathrm{H}, \mathrm{py}), 5.85-$ $5.73(\mathrm{~m}, 2 \mathrm{H}$, py), 4.67 (br, $1 \mathrm{H},=\mathrm{CH} \mathrm{COD}), 3.71(\mathrm{~m}, 3 \mathrm{H}$, $\left.\mathrm{PCH}\left(\mathrm{CH}_{3}\right)_{2}\right), 3.5$ (br, 2H, =CH COD), 2.80 (br, 1H, =CH COD), 2.28 (m, 3H, $\left.\mathrm{CH}_{2} \mathrm{COD}\right), 1.95$ (br, $\left.2 \mathrm{H}, \mathrm{CH}_{2} \mathrm{COD}\right), 1.46\left(\mathrm{~m}, 3 \mathrm{H}, \mathrm{CH}_{2}\right.$ COD), $1.30\left(\mathrm{dd}, J_{\mathrm{H}-\mathrm{H}}=7.2, J_{\mathrm{H}-\mathrm{P}}=12.0,9 \mathrm{H}, \mathrm{PCH}\left(\mathrm{CH}_{3}\right)_{2}\right), 1.21\left(\mathrm{dd}, J_{\mathrm{H}-}\right.$ $\left.\mathrm{H}=7.2, J_{\mathrm{H}-\mathrm{P}}=11.7,9 \mathrm{H}, \mathrm{PCH}\left(\mathrm{CH}_{3}\right)_{2}\right) .{ }^{1} \mathrm{H} \mathrm{NMR}\left(300 \mathrm{MHz}, \mathrm{C}_{7} \mathrm{D}_{8}, 223\right.$ $\mathrm{K}$, olefinic protons): $\delta 4.7(\mathrm{br}, 1 \mathrm{H},=\mathrm{CH}), 3.4(\mathrm{br}, 2 \mathrm{H},=\mathrm{CH}), 2.8(\mathrm{br}$, $1 \mathrm{H},=\mathrm{CH}) .{ }^{13} \mathrm{C}\left\{{ }^{1} \mathrm{H}\right\} \mathrm{NMR}\left(75.47 \mathrm{MHz}, \mathrm{C}_{6} \mathrm{D}_{6}, 298 \mathrm{~K}\right): \delta 160.9(\mathrm{~s}, \mathrm{C})$, 157.2 (s, C), 156.9 (s, C), 154.7 (s, CH py), 154.6 (s, C), 153.0 (s, C), 150.3 (s, C), 149.5, 149.0, 146.8, 140.1, 136.0, 135.1, 134.7, 130.4, $122.8,120.9,120.4,118.1,118.1,116.5,108.5,105.3,104.7$ (all s, $\mathrm{CH}$ py and pz), 32.9 (s, $\left.\mathrm{CH}_{2}, \mathrm{COD}\right), 29.4$ (s, $\left.\mathrm{CH}_{2}, \mathrm{COD}\right), 27.5$ (d, JC-P $\left.=23.4, \mathrm{PCH}\left(\mathrm{CH}_{3}\right)_{2}\right), 20.9,20.1$ (both s, PCH $\left.\left(\mathrm{CH}_{3}\right)_{2}\right) .{ }^{31} \mathrm{P}\left\{{ }^{1} \mathrm{H}\right\}$ NMR (121.49 MHz, $\left.\mathrm{C}_{6} \mathrm{D}_{6}, 298 \mathrm{~K}\right): \delta-4.0$.

General procedure for the catalytic dehydrogenations. A solution of complex $3(0.0093 \mathrm{mmol})$ and the corresponding alcohol $(0.19$ $\mathrm{mmol})$ in toluene $(1 \mathrm{~mL})$ was placed in a Schlenk flask equipped with 
a condenser and an oil bubbler. The reaction mixture was heated at $100{ }^{\circ} \mathrm{C}$ for $18 \mathrm{~h}$. After this time the solution was cooled to room temperature, and the extent of the reaction was determined by different methods depending on the nature of the alcohol. Reactions were run in duplicate.

For secondary alcohols the extent of the conversion to ketones was determined by CG on an Agilent Technologies $6890 \mathrm{~N}$ gas chromatograph with a flame ionization detector, using a HP-Innowax column ( $25 \mathrm{~m} \times 0.2 \mathrm{~mm}$, with $0.4 \mu \mathrm{m}$ film thickness). The oven conditions used are as follows: $80{ }^{\circ} \mathrm{C}$ (hold $5 \mathrm{~min}$ ) to $200^{\circ} \mathrm{C}$ at $15^{\circ} \mathrm{C} / \mathrm{min}$ (hold 7 min), except for diphenylmethanol $\left(150{ }^{\circ} \mathrm{C}\right.$ (hold $\left.5 \mathrm{~min}\right)$ to $240{ }^{\circ} \mathrm{C}$ at $15^{\circ} \mathrm{C} / \mathrm{min}$ (hold $\left.13 \mathrm{~min}\right)$ ). The identity of the ketones was confirmed by comparison of their retention times with those of pure products, as well as by GC-MS analyses. In the case of primary alcohols and diols, the crude solution was evaporated under reduced pressure to obtain an oil. Then, $0.187 \mathrm{mmol}(20 \mu \mathrm{L})$ of 1,1,2,2-tetrachloroethane was added as an internal standard, and the mixture was dissolved in $\mathrm{CDCl}_{3}$ and analyzed by ${ }^{1} \mathrm{H}$ NMR spectroscopy. The formed aldehydes, esters and lactones were characterized by ${ }^{1} \mathrm{H}$ NMR spectroscopy.

\section{ASSOCIATED CONTENT}

\section{Supporting Information}

The Supporting Information is available free of change on the ACS Publications web site:

General information, crystallographic data, computational details, and NMR spectra (pdf).

Cartesian coordinates of the optimized structures (XYZ).

\section{AUTHOR INFORMATION}

\section{Corresponding Author}

*E-mail: maester@unizar.es

\section{Author Contributions}

The manuscript was written through contributions of all authors. All authors have given approval to the final version of the manuscript.

\section{Notes}

The authors declare no competing financial interests

\section{ACKNOWLEDGMENT}

Financial support from the MINECO of Spain (Projects CTQ2017-82935-P and Red de Excelencia Consolider CTQ201681797-REDC), the Diputación General de Aragón (E06_17R), FEDER, and the European Social Fund is acknowledged.

\section{REFERENCES}

(1) (a) Kumar, G.; Gupta, R. Molecularly designed architectures the metalloligand way. Chem. Soc. Rev. 2013, 42, 9403-9453. (b) Liu, J.; Chen, L.; Cui, H.; Zhang, J.; Zhang, L.; Su, C.-Y. Applications of metal-organic frameworks in heterogeneous supramolecular catalysis. Chem. Soc. Rev. 2014, 43, 6011-6061. (c) Gil-Rubio, J.; Vicente, J. The Coordination and Supramolecular Chemistry of Gold Metalloligands. Chem. Eur. J. 2018, 24, 32-46.

(2) Bosnich, B. Cooperative Bimetallic Redox Reactivity. Inorg. Chem. 1999, 38, 2554-2562.

(3) (a) Esteruelas, M. A.; Garcia, M. P.; López, A. M.; Oro, L. A. Indirect cooperative effects leading to synergism in bimetallic homogeneous catalysts containing azolates as bridging ligands. Organometallics 1991, 10, 127-133. (b) Esteruelas, M. A.; Garcia, M. P.; López, A. M.; Oro, L. A. Hydrogen-transfer catalytic synergism in binuclear complexes containing 2,2'-biimidazolate as a bridging ligand. Organometallics 1992, 11, 702-705. (c) Hetterscheid, D. G. H.; Chikkali, S. H.; de Bruin, B.; Reek, J. N. H. Binuclear Cooperative Catalysts for the Hydrogenation and Hydroformylation of Olefins. ChemCatChem 2013, 5, 2785-2793.

(4) See for example: (a) Colacot, T. J. A Concise Update on the Applications of Chiral Ferrocenyl Phosphines in Homogeneous Catalysis Leading to Organic Synthesis. Chem. Rev. 2003, 103, 31013118. (b) Barbaro, P.; Bianchini, C.; Giambastiani, G.; Parisel, S. L. Progress in stereoselective catalysis by metal complexes with chiral ferrocenyl phosphines. Coord. Chem. Rev. 2004, 248, 2131-2150. (c) Fihri, A.; Meunier, P.; Hierso, J.-C. Performances of symmetrical achiral ferrocenylphosphine ligands in palladium-catalyzed crosscoupling reactions: A review of syntheses, catalytic applications and structural properties. Coord. Chem. Rev. 2007, 251, 2017-2055. (d) Toma, Š.; Csizmadiová, J.; Mečiarová, M.; Šebesta, R. Ferrocene phosphane-heteroatom/carbon bidentate ligands in asymmetric catalysis. Dalton Trans. 2014, 43, 16557-16579. (e) Štěpnička, P. Coordination and catalytic chemistry of phosphinoferrocene carboxamides. Coord. Chem. Rev. 2017, 353, 223-246.

(5) See for example: (a) Atkinson, R. C. J.; Gibson, V. C.; Long, N. J. The syntheses and catalytic applications of unsymmetrical ferrocene ligands. Chem. Soc. Rev. 2004, 33, 313-328. (b) Buchwalter, P.; Rosé, J.; Braunstein, P. Multimetallic Catalysis Based on Heterometallic Complexes and Clusters. Chem. Rev. 2015, 115, 28-126.

(6) (a) Baratta, W.; Bossi, G.; Putignano, E.; Rigo, P. Pincer and Diamine $\mathrm{Ru}$ and Os Diphosphane Complexes as Efficient Catalysts for the Dehydrogenation of Alcohols to Ketones. Chem. Eur. J. 2011, 17, 3474-3481. (b) Chelucci, G.; Baldino, S.; Baratta, W. Ruthenium and osmium complexes containing 2-(aminomethyl)pyridine (Ampy)based ligands in catalysis. Coord. Chem. Rev. 2015, 300, 29-85. (c) Chelucci, G.; Baldino, S.; Baratta, W. Recent Advances in OsmiumCatalyzed Hydrogenation and Dehydrogenation Reactions. Acc. Chem. Res. 2015, 48, 363-379.

(7) (a) Friedrich, A.; Schneider, S. Acceptorless Dehydrogenation of Alcohols: Perspectives for Synthesis and $\mathrm{H}_{2}$ Storage. ChemCatChem 2009, 1, 72-73. (b) Johnson, T. C.; Morris, D. J.; Wills, M. Hydrogen generation from formic acid and alcohols using homogeneous catalysts. Chem. Soc. Rev. 2010, 39, 81-88. (c) Gunanathan, C.; Milstein, D. Applications of acceptorless dehydrogenation and related transformations in chemical synthesis. Science 2013, 341, 1229712. (d) Trincado, M.; Banerjee, D.; Grützmacher, J. Molecular catalysts for hydrogen production from alcohols. Energy Environ. Sci. 2014, 7, 2464-2503. (e) Nielsen, M. Hydrogen Production by Homogeneous Catalysis: Alcohol Acceptorless Dehydrogenation. In Hydrogen Production and Remediation of Carbon and Pollutants; Lichtfouse, E.; Schwarzbauer, J.; Robert, D. (eds), Springer: Switzerland, 2015; Chapter 1, pp 1-60.

(8) (a) Zhang, J.; Gandelman, M.; Shimon, L. J. W.; Rozenberg, H.; Milstein, D. Electron-Rich, Bulky Ruthenium PNP-Type Complexes. Acceptorless Catalytic Alcohol Dehydrogenation. Organometallics 2004, 23, 4026-4033. (b) Zhang, J.; Leitus, G.; Ben-David, Y.; Milstein, D. Facile Conversion of Alcohols into Esters and Dihydrogen Catalyzed by New Ruthenium Complexes. J. Am. Chem. Soc. 2005, 127, 10840-10841. (c) Musa, S.; Shaposhnikov, I.; Cohen, S.; Gelman, D. Ligand-Metal Cooperation in PCP Pincer Complexes: Rational Design and Catalytic Activity in Acceptorless Dehydrogenation of Alcohols. Angew. Chem. Int. Ed. 2011, 50, 3533-3537. (d) Nielsen, M.; Kammer, A.; Cozzula, D.; Junge, H.; Gladiali, S.; Beller, M. Efficient Hydrogen Production from Alcohols under Mild Reaction Conditions. Angew. Chem. Int. Ed. 2011, 50, 9593-9597. (e) Kamitani, M.; Ito, M.; Itazaki, M.; Nakazawa, H. Effective dehydrogenation of 2-pyridylmethanol derivatives catalyzed by an iron complex. Chem. Commun. 2014, 50, 7941-7944. (f) Song, H.; Kang, B.; Hong, S. H. Fe-Catalyzed Acceptorless Dehydrogenation of Secondary Benzylic Alcohols. ACS Catal. 2014, 4, 2889-2895. (g) Sengupta, D.; Bhattacharjee, R.; Pramanick, R.; Rath, S. P.; Chowdhury, N. S.; Datta, A.; Goswami, S. Exclusively Ligand-Mediated Catalytic Dehydrogenation of Alcohols. Inorg. Chem. 2016, 55, 9602-9610. (h) Dutta, I.; Sarbajna, A.; Pandey, P.; Rahaman, S. M. W.; Singh, K.; Bera, J. K. Acceptorless Dehydrogenation of Alcohols on a Diruthenium(II,II) Platform. Organometallics 2016, 35, 1505-1513. (i) Toyomura, K.; Fujita, K. Synthesis of Coordinatively Unsaturated Iridium Complexes Having Functional 8-Quinolinolato Ligands: New 
Catalysts for Dehydrogenative Oxidation of Alcohols in Aqueous Media. Chem. Lett. 2017, 46, 808-810. (j) Wang, Z.; Pan, B.; Liu, Q.; Yue, E.; Solan, G. A.; Ma, Y.; Sun, W.-H. Efficient acceptorless dehydrogenation of secondary alcohols to ketones mediated by a PNN-Ru(II) catalyst. Catal. Sci. Technol. 2017, 7, 1654-1661. (k) Wang, Q.; Chai, H.; Yu, Z. Dimeric Ruthenium(II)-NNN Complex Catalysts Bearing a Pyrazolyl-Pyridylamino-Pyridine Ligand for Transfer Hydrogenation of Ketones and Acceptorless Dehydrogenation of Alcohols. Organometallics 2017, 36, 3638-3644. (1) Sarbajna, A.; Dutta, I.; Daw, P.; Dinda, S.; Rahaman, S. M. W.; Sarkar, A.; Bera, J. K. Catalytic Conversion of Alcohols to Carboxylic Acid Salts and Hydrogen with Alkaline Water. ACS Catal. 2017, 7, 2786-2790. (m) Huang, R.; Yang, Y.; Wang, D.-S.; Zhang, L.; Wang. D. Where does $\mathrm{Au}$ coordinate to $\mathrm{N}$-(2-pyridiyl)benzotriazole: gold-catalyzed chemoselective dehydrogenation and borrowing hydrogen reactions. Org. Chem. Front. 2018, 5, 203-209.

(9) (a) Kawahara, R.; Fujita, K.; Yamaguchi, R. Dehydrogenative Oxidation of Alcohols in Aqueous Media Using Water-Soluble and Reusable Cp*Ir Catalysts Bearing a Functional Bipyridine Ligand. J. Am. Chem. Soc. 2012, 134, 3643-3646. (b) Kawahara, R.; Fujita, K.; Yamaguchi, R. Cooperative Catalysis by Iridium Complexes with a Bipyridonate Ligand: Versatile Dehydrogenative Oxidation of Alcohols and Reversible Dehydrogenation-Hydrogenation between 2Propanol and Acetone. Angew. Chem. Int. Ed. 2012, 51, 1279012794. (c) Chakraborty, S.; Lagaditis, P. O.; Förster, M.; Bielinski, E. A.; Hazari, N.; Holthausen, M. C.; Jones, W. D.; Schneider, S. WellDefined Iron Catalysts for the Acceptorless Reversible Dehydrogenation-Hydrogenation of Alcohols and Ketones. ACS Catal. 2014, 4, 3994-4003. (d) Zeng, G.; Sakaki, S.; Fujita, K.; Sano, H.; Yamaguchi, R. Efficient Catalyst for Acceptorless Alcohol Dehydrogenation: Interplay of Theoretical and Experimental Studies. ACS Catal. 2014, 4, 1010-1020. (e) Bonitatibus, P. J., Jr.; Chakraborty, S.; Doherty, M. D.; Siclovan, O.; Jones, W. D.; Soloveichik, G. L. Reversible catalytic dehydrogenation of alcohols for energy storage. PNAS 2015, 112, 1687-1692. (f) Valencia, M.; Müller-Bunz, H.; Gossage, R. A.; Albrecht, M. Enhanced product selectivity promoted by remote metal coordination in acceptor-free alcohol dehydrogenation catalysis. Chem. Commun. 2016, 52, 3344-3347. (g) Mazloomi, Z.; Pretorius, R.; Pàmies, O.; Albrecht, M.; Diéguez, M. Triazolylidene Iridium Complexes for Highly Efficient and Versatile Transfer Hydrogenation of $\mathrm{C}=\mathrm{O}, \mathrm{C}=\mathrm{N}$, and $\mathrm{C}=\mathrm{C}$ Bonds and for Acceptorless Alcohol Oxidation. Inorg. Chem. 2017, 56, 11282-11298. (h) Fujita, K.; Tamura, R.; Tanaka, Y.; Yoshida, M.; Onoda, M.; Yamaguchi, R. Dehydrogenative Oxidation of Alcohols in Aqueous Media Catalyzed by a WaterSoluble Dicationic Iridium Complex Bearing a Functional $\mathrm{N}$-Heterocyclic Carbene Ligand without Using Base. ACS Catal. 2017, 7, 7226-7230. (i) Vivancos, Á.; Petronilho, A.; Cardoso, J.; Müller-Bunz, H.; Albrecht, M. Unveiling the role of ancillary ligands in acceptorless benzyl alcohol dehydrogenation and etherification mediated by mesoionic carbene iridium complexes. Dalton Trans. 2018, 47, 74-82. (j) González Miera, G.; Martínez-Castro, E.; MartínMatute, B. Acceptorless Alcohol Dehydrogenation: OH vs NH Effect in Bifunctional NHC-Ir(III) Complexes. Organometallics 2018, 37, 636-644.

(10) (a) Dub, P. A.; Henson, N. J.; Martin, R. L.; Gordon, J. C. Unravelling the Mechanism of the Asymmetric Hydrogenation of Acetophenone by $\left[\mathrm{RuX}_{2}\right.$ (diphosphine)(1,2-diamine)] Catalysts. J. Am. Chem. Soc. 2014, 136, 3505-3521. (b) Dub, P. A.; Gordon, J. C. The mechanism of enantioselective ketone reduction with Noyori and Noyori-Ikariya bifunctional catalysts, Dalton Trans. 2016, 45, 67566781. (c) Dub, P. A.; Gordon, J. C. Metal-Ligand Bifunctional Catalysis: The "Accepted" Mechanism, the Issue of Concertedness, and the Function of the Ligand in Catalytic Cycles Involving Hydrogen Atoms. ACS Catal. 2017, 7, 6635-6655.

(11) (a) Gusev, D. G. Dehydrogenative Coupling of Ethanol and Ester Hydrogenation Catalyzed by Pincer-Type YNP Complexes. ACS Catal. 2016, 6, 6967-6981. (b) Morris, S. A.; Gusev, D. G. Rethinking the Claisen-Tishchenko Reaction. Angew. Chem. Int. Ed. 2017, 56, 6228-6231. (c) Gusev, D. G. Rethinking the Dehydrogenative Amide Synthesis. ACS Catal. 2017, 7, 6656-6662.
(12) (a) Esteruelas, M. A.; Lahoz, F. J.; López, A. M.; Oñate, E.; Oro, L. A.; Ruiz, N.; Sola, E.; Tolosa, J. I. Quantum Mechanical Exchange Coupling in Trihydridoosmium Complexes Containing Azole Ligands. Inorg. Chem. 1996, 35, 7811-7817. (b) Mayboroda, A.; Comba, P.; Pritzkow, H.; Rheinwald, G.; Lang, H.; van Koten, G. Heterotrinuclear Complexes of the Platinum Group Metals with 2,2Biimidazole as a Bridging Ligand. Eur. J. Inorg. Chem. 2003, 17031710.

(13) See for example: (a) Esteruelas, M. A.; Fernández-Alvarez, F. J.; Oliván, M.; Oñate, E. C-H Bond Activation and Subsequent C-C Bond Formation Promoted by Osmium: 2-Vinylpyridine-Acetylene Couplings. J. Am. Chem. Soc. 2006, 128, 4596-4597. (b) Bolaño, T.; Esteruelas, M. A.; Oñate, E. Osmium-carbon multiple bonds: Reduction and C-C coupling reactions. J. Organomet. Chem. 2011, 696, 3911-3923. (c) Collado, A.; Esteruelas, M. A.; Gulías, M.; Mascareñas, J. L.; Oñate, E. Reactions of an Osmium(IV) Complex with Allenedienes: Coordination and Intramolecular Cycloadditions. Organometallics 2012, 31, 4450-4458. (d) Esteruelas, M. A.; Fernández, I.; López, A. M.; Mora, M.; Oñate, E. Preparation, Structure, Bonding, and Preliminary Reactivity of a Six-Coordinate $\mathrm{d}^{4}$ Osmium-Boryl Complex. Organometallics 2012, 31, 4646-4649. (e) Casanova, N.; Esteruelas, M. A.; Gulías, M.; Larramona, C.; Mascareñas, J. L.; Oñate, E. Amide-Directed Formation of Five-Coordinate Osmium Alkylidenes from Alkynes. Organometallics 2016, 35, 91-99. (f) Esteruelas, M. A.; Lezáun, V.; Martínez, A.; Oliván, M.; Oñate, E. Osmium Hydride Acetylacetonate Complexes and Their Application in Acceptorless Dehydrogenative Coupling of Alcohols and Amines and for the Dehydrogenation of Cyclic Amines. Organometallics 2017, 36, 2996-3004.

(14) Alabau, R. G.; Esteruelas, M. A.; Oliván, M.; Oñate, E. Preparation of Phosphorescent Osmium(IV) Complexes with N,N',C and C,N,C'-Pincer Ligands. Organometallics 2017, 36, 1848-1859.

(15) Churchill, M. W.; Bezman, S. A. X-Ray Crystallographic Studies on Fluxional Pentacoordinate Transition Metal Complexes. III. (Cycloocta-1,5-diene) [1,3 bis(diphenylphosphino)propane]methyliridium(I). Inorg. Chem. 1973, 12, 531-536.

(16) Martínez, A. P.; Fabra, M. J.; García, M. P.; Lahoz, F. J.; Oro, L. A.; Teat, S. J. Mononuclear rhodium and iridium compounds with pyridyl-pyrazole ligands. Inorg. Chim. Acta 2005, 358, 1635-1644.

(17) Chakraborty, S.; Piszel, P. E.; Brennessel, W. W.; Jones, W. D. A Single Nickel Catalyst for the Acceptorless Dehydrogenation of Alcohols and Hydrogenation of Carbonyl Compounds. Organometallics 2015, 34, 5203-5206.

(18) Buil, M. L.; Esteruelas, M. A.; Gay, M. P.; Gómez-Gallego, M.; Nicasio, A. I.; Oñate, E.; Santiago, A.; Sierra, M. A. Osmium Catalysts for Acceptorless and Base-Free Dehydrogenation of Alcohols and Amines: Unusual Coordination Modes of a BPI Anion. Organometallics 2018, 37, 603-617.

(19) See for example: (a) Esteruelas, M. A.; Hernández, Y. A.; López, A. M.; Oliván, M.; Rubio, L. Reactions of a DihydrideOsmium(IV) Complex with Aldehydes: Influence of the Substituent at the Carbonyl Group. Organometallics 2008, 27, 799-802. (b) Alós, J.; Esteruelas, M. A.; Oliván, M.; Oñate, E.; Puylaert; P. C-H Bond Activation Reactions in Ketones and Aldehydes Promoted by POPPincer Osmium and Ruthenium Complexes. Organometallics 2015, $34,4908-4921$.

(20) (a) Murahashi, S.-I.; Naota, T.; Ito, K.; Maeda, Y.; Taki, H. Ruthenium-Catalyzed Oxidative Transformation of Alcohols and Aldehydes to Esters and Lactones. J. Org. Chem. 1987, 52, 43194327. (b) Zhang, J.; Balaraman, E.; Leitus, G.; Milstein, D. ElectronRich PNP- and PNN-Type Ruthenium(II) Hydrido Borohydride Pincer Complexes. Synthesis, Structure, and Catalytic Dehydrogenation of Alcohols and Hydrogenation of Esters. Organometallics 2011, 30, 5716-5724. (c) Langer, R.; Fuchs, I.; Vogt, M.; Balaraman, E.; Diskin-Posner, Y.; Shimon, L. J. W.; Ben-David, Y.; Milstein, D. Stepwise Metal-Ligand Cooperation by a Reversible Aromatization/Deconjugation Sequence in Ruthenium Complexes with a Tetradentate Phenanthroline-Based Ligand. Chem. Eur. J. 2013, 19, $3407-$ 3414. (d) Nguyen, D. H.; Trivelli, X.; Capet, F.; Swesi, Y.; FavreRéguillon, A.; Vanoye, L.; Dumeignil, F.; Gauvin, R. M. Deeper 
Mechanistic Insight into Ru Pincer-Mediated Acceptorless Dehydrogenative Coupling of Alcohols: Exchanges, Intermediates, and Deactivation Species. ACS Catal. 2018, 8, 4719-4734.

(21) $\sigma_{\mathrm{p}}$ values taken from March, J. Advanced Organic Chemistry, $3^{\text {rd }}$ Edition, Wiley Interscience, 1985.

(22) See for example: (a) Lin, Y.; Zhu, X.; Zhou, Y. A convenient lactonization of diols to $\gamma$ - and $\delta$-lactones catalysed by transition metal polyhydrides. J. Organomet. Chem. 1992, 429, 269-274. (b) Suzuki, T.; Morita, K.; Tsuchida, M.; Hiroi, K. Mild and Chemoselective Synthesis of Lactones from Diols Using a Novel Metal-Ligand Bifunctional Catalyst. Org. Lett. 2002, 4, 2361-2363.

(23) (a) Ito, M.; Osaku, A.; Shiibashi, A.; Ikariya, T. An Efficient Oxidative Lactonization of 1,4-Diols Catalyzed by $\mathrm{Cp} * \mathrm{Ru}(\mathrm{PN}) \mathrm{Com}-$ plexes. Org. Lett. 2007, 9, 1821-1824. (b) Dutta, I.; Sarbajna, A.; Pandey, P.; Rahaman, S. M. W.; Singh, K.; Bera, J. K. Acceptorless Dehydrogenation of Alcohols on a Diruthenium(II,II) Platform. Organometallics 2016, 35, 1505-1513.

(24) Zhao; J.; Hartwig, J. F Acceptorless, Neat, RutheniumCatalyzed Dehydrogenative Cyclization of Diols to Lactones. Organometallics 2005, 24, 2441-2446

(25) See for example: (a) Nielsen, M.; Kammer, A.; Cozzula, D.; Junge, H.; Gladiali, S.; Beller, M. Efficient Hydrogen Production from Alcohols under Mild Reaction Conditions. Angew. Chem. Int. Ed. 2011, 50, 9593-9597. (b) Tseng, K.-N. T.; Kampf, J. W.; Szymczak, N. K. Mechanism of N,N,N-Amide Ruthenium(II) Hydride Mediated Acceptorless Alcohol Dehydrogenation: Inner-Sphere $\beta$-H Elimination versus Outer-Sphere Bifunctional Metal-Ligand Cooperativity. ACS Catal. 2015, 5, 5468-5485. (c) de Boer, S. Y.; Korstanje, T. J.; La Rooij, S. R.; Kox, R.; Reek, J. N. H.; van der Vlugt, J. I. Ruthenium PNN(O) Complexes: Cooperative Reactivity and Application as Catalysts for Acceptorless Dehydrogenative Coupling Reactions. Organometallics 2017, 36, 1541-1549. (d) Wang, Q.; Chai, H.; Yu, Z. Acceptorless Dehydrogenation of N-Heterocycles and Secondary Alcohols by Ru(II)-NNC Complexes Bearing a Pyrazoyl-indolylpyridine Ligand. Organometallics 2018, 37, 584-591.

(26) (a) Choi, J.; MacArthur, A. H. R.; Brookhart, M.; Goldman, A. S. Dehydrogenation and Related Reactions Catalyzed by Iridium Pincer Complexes. Chem. Rev. 2011, 111, 1761-1779. (b) Haibach, M. C.; Kundu, S.; Brookhart, M.; Goldman, A. S. Alkane Metathesis by Tandem Alkane-Dehydrogenation Olefin-Metathesis Catalysis and Related Chemistry. Acc. Chem. Res. 2012, 45, 947-958. (c) Esteruelas, M. A.; López, A. M.; Oliván, M. Polyhydrides of Platinum Group Metals: Nonclassical Interactions and $\sigma$-Bond Activation Reactions. Chem. Rev. 2016, 116, 8770-8847. (d) Kumar, A.; Bhatti, T. M.; Goldman, A. S. Dehydrogenation of Alkanes and Aliphatic Groups by Pincer-Ligated Metal Complexes. Chem. Rev. 2017, 117, $12357-12384$

(27) (a) Qu, S.; Dang, Y.; Song, C.; Wen, M.; Huang, K.-W.; Wang, Z.-X. Catalytic Mechanisms of Direct Pyrrole Synthesis via Dehydrogenative Coupling Mediated by PNP-Ir or PNN-Ru Pincer Complexes: Crucial Role of Proton-Transfer Shuttles in the PNP-Ir System. J. Am. Chem. Soc. 2014, 136, 4974-4991. (b) Hou, C.; Zhang, Z.; Zhao, C.; Ke. Z. DFT Study of Acceptorless Alcohol Dehydrogenation Mediated by Ruthenium Pincer Complexes: Ligand Tautomerization Governing Metal Ligand Cooperation. Inorg. Chem. 2016, 55, 6539-6551.

(28) (a) Esteruelas, M. A.; Oro, L. A. Dihydrogen Complexes as Homogeneous Reduction Catalysts. Chem. Rev. 1998, 98, 577-588. (b) Morris, R. H. Brønsted-Lowry Acid Strength of Metal Hydride and Dihydrogen Complexes. Chem. Rev. 2016, 116, 8588-8654.

(29) Aracama, M.; Esteruelas, M. A.; Lahoz, F. J.; Lopez, J. A.; Meyer, U.; Oro, L. A.; Werner, H. Synthesis, Reactivity, Molecular Structure, and Catalytic Activity of the Novel Dichlorodihydridoosmium(IV) Complexes $\mathrm{OsH}_{2} \mathrm{Cl}_{2}\left(\mathrm{PR}_{3}\right)_{2}\left(\mathrm{PR}_{3}=\mathrm{P}-i-\mathrm{Pr}_{3}, \mathrm{PMe}-t-\mathrm{Bu}_{2}\right)$. Inorg. Chem. 1991, 30, 288-293.

(30) Usón, R.; Oro, L. A.; Cabeza, J. A. Dinuclear Methoxy, Cyclooctadiene, and Barrelene Complexes of Rhodium(I) and Iridium(I). Inorg. Synth. 1985, 23, 126-130. 


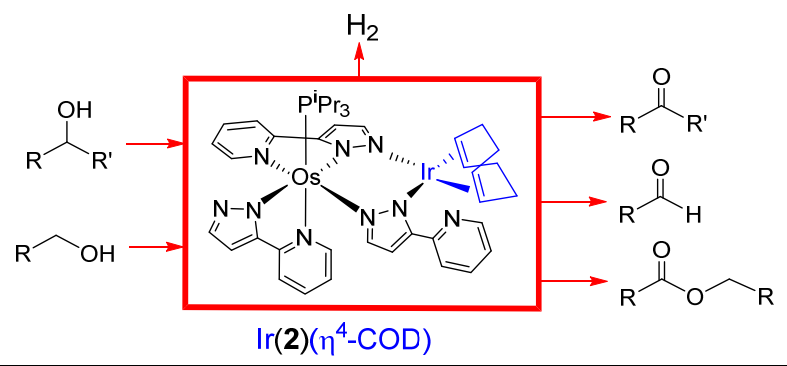

10 